\title{
STUDY OF HR MANAGEMENT FOR A DEVELOPMENT IN LEARNING STRATEGIES IN THE NEW NORMAL ERA
}

\author{
Ahnis Zulkarnain, Rizni Restiana \\ Polytechnic Penerbangan Medan \\ E-mail: ahniszulkarnain@gmail.com ,riznirestiana@gmail.com
}

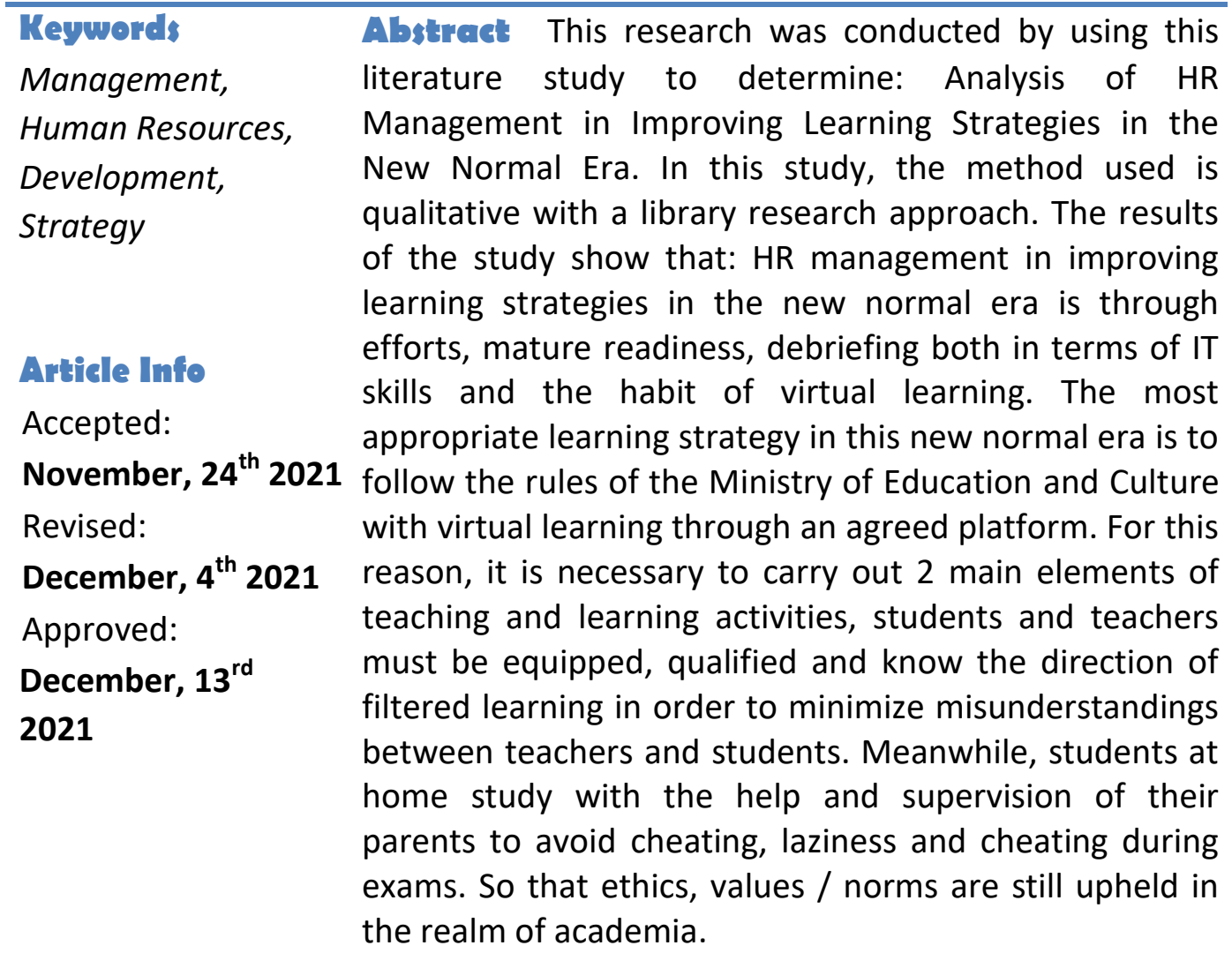

\section{Introduction}

Covid -19 (Coronavirus disease 2019) affects most aspects of human life (Adam, 2020) without exception in the education aspect, especially in Indonesia. The government is also reluctant to quickly respond to these impacts during the 


\section{Ahnis Zulkarnain, Rizni Restiana}

pandemic, one of which is by releasing a guide book "Organizing Learning in the Academic Year and Academic Year 2020/2021 During the Coronavirus Disease (Covid-19) Pandemic" by a joint decision of 4 (four) Ministers including the Minister of Education and Culture, Minister of Religion, Minister of Health and Minister of Home Affairs on June 30, 2020. Activities in the learning process in Indonesia during the COVID-19 pandemic have so far been carried out online. And in its implementation, it turns out that it still needs some adaptations and improvements. Based on the quality of the factors supporting the implementation of the learning process, these supporting factors include devices, computers, internet connections, and television (Putria et al, 2020).

Consciously, we know that human resource management is a core part of an association or an educational institution. Not to be missed in this, how the human resources themselves dedicate themselves to welcoming the transition from normal (as usual) to a pandemic (because it has hit dozens of countries in the world) to become a new normal (normal with new habits). Why was the new normal era chosen instead of the original normal? Because at this time we have been required to be ready, after several months of refraining like the process of fasting from leaving the house for things that are not needed. Even some people are required to remain silent for an undetermined time as a form of endeavor for the pandemic that may befall those who are not picky/know anyone. Almost more than 3 months, both government agencies, education and elements that require too much physical contact have to be temporarily stopped in order to follow the rules of physical distancing to prevent this fast-growing virus from spreading (Arafah \& Bahri, 2020). Regarding the world of education, where children have longer holidays than usual, even based on the glasses that are seen now, boredom and boredom begin to decorate themselves as excuses for missing, teachers, peers, lessons at school and activities that they usually do. Indeed, educational institutions also follow a fast-paced path so that they continue to hold learning that is functioned by the online method.

Learning strategies referring to the new normal era are guided by following health protocols and triggering teachers as part of the most important human resources in teaching and learning activities to have precise moves to manage learning without face-to-face without eliminating the learning essence itself. As currently circulating on social media, teachers often provide examples and then share links and ask students to follow them at home, which is an efficient way to learn in the midst of a pandemic with the new normal era (Miftah sa'adah \& Rakimahwati, 2021).

However, the ineffectiveness of both human resources, in this case 
educators, students and parents, found various obstacles with the virtual method applied to this new civilization of human life. Therefore, HR must be familiar with its power to improve by innovating with new strategies to smooth teaching and learning activities in the era that is currently being lived. Experts have also researched for a long time so that their findings are as stated by Ni'mah that: there are also obstacles from this E-learning, namely: 1) Electricity can go out while accessing learning programs 2) Bad internet network 3) Uncertain commitment from parents 4) Students/students who find it difficult to learn this way 5) Misunderstanding between lecturers/teachers and students/students 6) Ignorance of science and technology (Lutfiah, 2020).

\section{Research Method}

The main method that became the basis for collecting data in this study led to the study conducted, namely a literature review, which is a search and summarize some empirical literature that is appropriate and relevant to the theme. The literature used is in the form of books, scientific articles from international and national journals. The literature used is literature relevant to this study and has been printed or published. The use of inclusion and exclusion criteria for the entire literature is the selection method.

On the other hand, the form of the data in this journal leads to descriptive data where the definition of descriptive is: "Descriptive research is research conducted to determine the existence of independent variables, either only on one or more variables without making comparisons or connecting with other variables (independent variables). is a variable that stands alone, not an independent variable, because if the independent variable is always paired with the dependent variable. "This method is intended to collect historical data and observe carefully about certain aspects related to the problem being studied so that it will obtain data - data that can support the preparation of the analysis report.This analysis involves the entire population (Nonprobability Sampling).

\section{Result and Discussion}

\section{Human Resource Management}

Human resource management is not a goal and the end of a process, but a device or tool to help achieve an overall goal. For this reason, a human resource management unit/section in an institution is established to serve other parts of the institution or organization. Human Resource Management is defined 


\section{Ahnis Zulkarnain, Rizni Restiana}

by Mangkunegara as a processing and utilization of resources that exist in individuals (Sakban, Nurmal, \& Ridwan, 2019). In another sense, it is a planning, organizing, implementing supervision of procurement, development, remuneration, integration, maintenance and separation of workers in order to achieve the goals of an institution. Human resource management in each institution/organization must be in accordance with organizational goals without being excessive or not too less. This is because there is an excess or lack of target application in each institutional unit, indicating that there is wasted or wasteful use of human resources. Therefore, every institutional unit that manages or uses human resources must be able to maintain the right balance between the quality and quantity of their respective resources. In order to be in line with the goals that have been set. In other words, what is necessary and main in management in this case are 3 components of human resources, namely teachers as educators, students as students and the main person as education stakeholders. And the link to participate between the community and parents is the main thing that is no less important.

Establishing cooperation between schools and the community is a form of activity carried out either directly or indirectly. For example, assistance and support from parties in the education environment (Fatmawati, 2020). Although, all levels of society have not fully contributed, but educational institutions must continue to be optimistic and aggressive to carry out socialization and interrelated activities for optimal goals achieved (Setiana, 2018). As part of the dominant micro component determining the quality of education, teachers must be qualified and perform well in globalization by trying to master various information and communication technologies. This is because the advancement of information and communication aspects has undergone tremendous changes in the era of globalization. In the national education system, teachers have a strategic role in the learning process in particular and the education process as a whole. Especially in the midst of a pandemic and the new normal transition period of the current era. It is very important for the 2 main elements above to share and care with each other to be able to balance the psychological condition of children who are depressed with limited activities that may have a stressor impact. So, this can be prevented by minimizing gaps with routines that keep going with extra supervision from the previous normal era.

\section{Ways of Handling Change}

The paradigm shift in managing organizations in an unpredictable and complex era makes organizations need to make adjustments through a process 
of change. Organizational change is an effort to maintain survival in order to survive in the face of uncertain problems such as Covid-19 (Taufik \& Warsono, 2020). Organizations that adapt quickly to environmental changes are organizations that survive

There are 2 main approaches to dealing with organizational change that managers can use, as shown below:

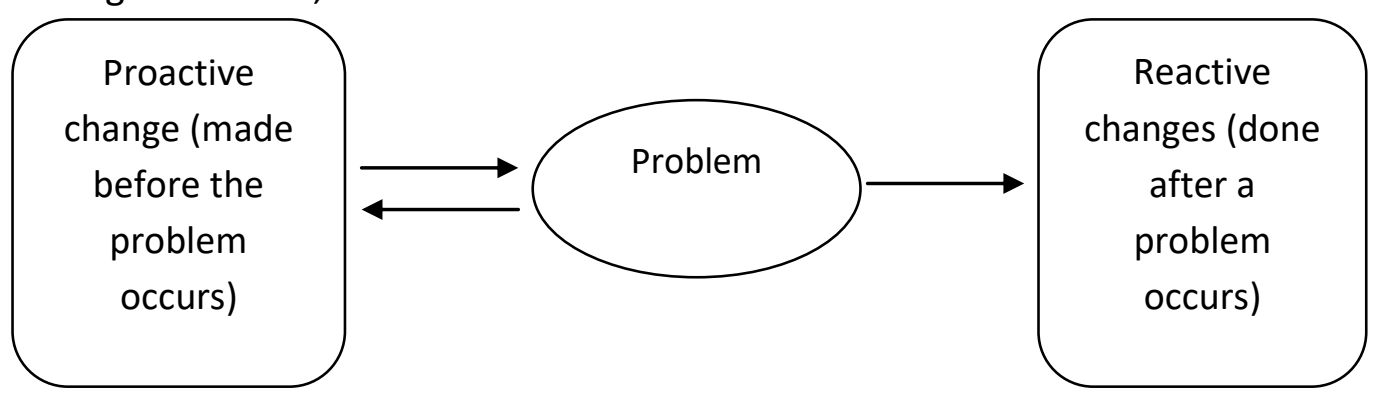

The first is a reactive change process, in which the leader reacts to signs that change is needed, implementing incremental modifications to deal with certain problems that arise. Second, the leader develops a program of planned change, often referred to as a proactive process, through making significant investments of time and other resources to change the way the institution/organization operates. The first approach is simpler and cheaper than the second approach. It takes a leader in solving simple (minor) problems and day-to-day adjustments that are integral to the position.

The second approach, a planned change program involves deliberate activities to change the status quo. Thimas and Bennis define planned change as the design and implementation of a new structural innovation, policy or goal, or a deliberate change in philosophy, climate and operations. This approach is appropriate when the entire institution/organization has to prepare for or adapt to change.

This can be seen from the spread of the pandemic that has occurred in the world, especially in our beloved country, Indonesia with the distinctive national anthem Indonesia Raya. The relevance is that we really need to react according to the second approach from the expert opinion above. Because it is impossible to predict when this pandemic will end completely. Wallahu'alam. Our task as academics is to always make efforts by entrusting the experts, namely the medical and the Education Office, who have gone to great lengths to design or renovate educational reforms that are adapted to the new normal era which is being gradually implemented in the distribution of 34 provinces of Indonesia. 


\section{Ahnis Zulkarnain, Rizni Restiana}

One of the efforts is to actively participate in webinars during the pandemic. From here, we can share directly with designers, initiators and policy makers in Indonesia, even with a limited time. In line with the Ministry of Education and Culture's statement, Romi said from the conclusion of the webinar held on Monday/07/07/2020 that we need to complement each other, teach, share experiences and collaborate. Similar to Miss Riska, as the manager of the KAIZEN educational institution, on this occasion also expressed the importance of collaboration between the school environment and the surrounding environment in the midst of this pandemic..

\section{HR Capability Development}

1. Good service can only be realized if HR management is carried out by prioritizing the interests of education service users.

2. Communication. Purwanto in his book argues that communication as an intermediary from conveying one's ideology to others certainly has obstacles and obstacles that can trigger misunderstandings. Communication inhibiting factors exist in several ways, including "problems in developing messages, problems in delivering messages, problems in receiving messages and problems in interpreting messages". As Rizal also revealed, communication between educators and students takes place in two directions which is bridged by the use of media, such as computers, television, radio, telephone, internet, video, and so on.

3. Global network, this stage started from the mid-1990s. It is called a global network because companies are connected to a global network of information technology systems with telecommunications technology via the internet, which is also popular with information technology systems. In other ways, emphasis is placed on the application of information9.

4. PDCA (Plan, Do, Check and Act) and SDCA (Standardize, Do, Check, and Act) cycles (Riniwati, 2016)

Expert expert Edward Deming as the initiator of this cycle, is a cycle to carry out continuous process improvement and control which includes the following steps:

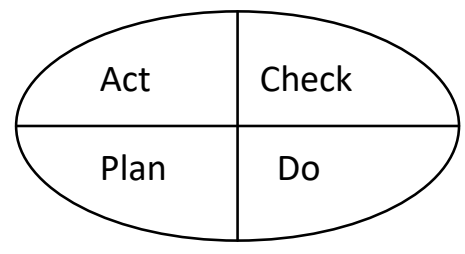


Steps Plans:

1. Identify the main problem

2. Research the root cause

3. Determine the influential cause.

4. Improvement plan, setting goals

Do :

5. Responsibility and implementation of the plan

Checks:

6. Evaluation and validation of implementation

Act :

7. Review all feedback, make improvements

8. Improve standard

Initially repair, each new process is usually not stable. Before making repairs for the next cycle, the new process is stabilized through SDCA which is maintenance. Here's a picture of SDCA maintenance:

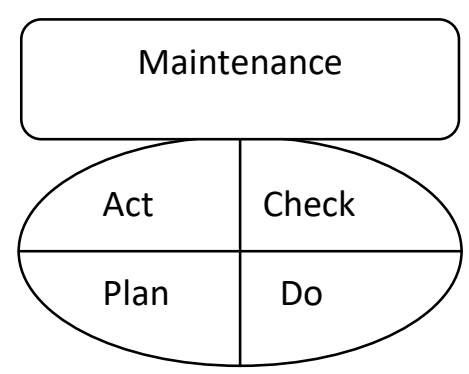

Figure 1. (SDCA Maintenance)

When an irregularity arises in a new process, several questions must be asked as a correction material, namely whether it occurs because there is no standard or the standard is not being adhered to, it could be less detailed or not detailed. After the standard is refined and complied with and brings stability to the process, it is allowed to move on to the next PDCA cycle. This indicates that the SDCA cycle applies standardization in order to achieve process stability with a maintenance function, while the PDCA cycle applies the repair and control function10.

This transition process really has to be prepared, starting from the services, communication, gliobal networks and cycles offered by Edward Deming above. Services that are viewed from a new civilization where virtual meetings are facilities that have been taken by our current educational unit with various application features provided, the most dominant are: zoom, google-meet, live in youtube, teacher's room, study room and various kinds other online discussions 


\section{Ahnis Zulkarnain, Rizni Restiana}

that have been held in cyberspace. All of this also has impacts and obstacles as we know that not all Indonesian students/people hold gadgets, inadequate signal access for remote areas, large internet quotas that are used in the midst of lack of income, and a teacher who must be willing to come to his students' homes. in order to get a proper education. Appreciation is at the same time sad, because the extra effort and the unsung teacher's motto attached to it have not yet reached the maximum level in implementation in the field.

\section{Towards the New Normal Transition Era}

In this new, unprecedented reality, post-Covid 19, the world is shocked by the term new normal, which results in restructuring (rearrangement) of people's lives, and in the near future, there will be debates and discussions about the new normal. The term "new normal" which means normality or new normal, has been around for a long time and is not foreign (Siahaya, Arsawan, Kennedy, Dewi, \& Aziz, n.d.). The government's steps to implement the new normal are very appropriate. As for the madrasa and school community, it is very important to pay attention to these steps towards the successful implementation of the new normal by of course paying attention to procedures.

Various terms are used to understand this term, such as a new life order (says Mr. Joko Widodo), adaptation of new habits (says Mr. Ridwan Kamil), transitions to welcome a new normal (says Mr. Anies Baswedan and Mr. Bima Arya), and lifestyle adjustments (says Wiku Asisasmita as the head of the expert team for the Covid-19 14 acceleration task force. The Ministry of Education and Culture (Kemendikbud) in its official Instagram account explained that the word new normal has an Indonesian equivalent, namely the new normal, which is a new normal that has never existed before15. According to a government spokesman in accelerating the handling of COVID 19, the new normal is interpreted as a movement for a new life, a productive and safe life from the corona virus outbreak. Achmad Yurianto said that we cannot return to the situation as before (the old normal), therefore we must changed 16 .

The substance of the new normal should not be considered limited to easing PSBB and public transportation. Although many were surprised, it was finally understood as something normal and should work. According to Ridwan Sanjaya, quoting Paul Glover's opinion in the Philadelphia City Paper 2009 that in explaining a condition that was originally considered unusual to be something that is then considered normal, natural, and finally widely accepted, the new normal accepted by the community becomes something which is then understood as a condition reasonable. These various changes that continue to 
occur create conditions known as "the new normal". The new normal has various responses from the public. This is natural, as long as it is intended for a better life and is carried out based on valid research studies.

WHO has set several barometers before the government implements the new normal, including: ensuring controlled transmission, the health system is in good condition, guaranteeing preventive measures in the work environment, preventing imported cases of covid, and ensuring public awareness and participation18. In line with that, the government has determined three standards for reducing PSBB, namely by looking at transmission based on the reproduction rate ( $\mathrm{RO})$, the level of health system capacity in responding to Covid-19 services and the level of mass Covid-19 tests carried out.

Looking at and observing the standards and barometers above, University of Indonesia epidemiologist Pandu Riono, quoted from You Tube Kompas TV, Saturday, May 30, 2020, assessed that the new life movement (new normal) could not be implemented in its entirety, if the health parameters had not been met, due to thoroughness. or the authenticity of the COVID-19 data, making it difficult to calculate the reproduction rate (RO)20. According to Jusuf Kalla, quoted from Akurat. Com, Saturday, May 30, 2020, predicts that the new normal will last at least 3 (three) years, if a covid 19 vaccine has been found in February 2021 and next is mass production of vaccines in August and September 202121. Many countries have decided to return to the life movement. new normal, such as China (China and South Korea but still following health protocols. But in the end, the country re-imposed social restrictions.

The phenomenon above, agrees with the announcement that is often conveyed by University of Indonesia epidemiologist Pandu Riono, quoted from Kompas, 29 May 2020: "If you continue to impose the implementation of the new normal phase, while the requirements and criteria that have been determined have not been met, then be prepared to bear the increase. case" 22 .

The author is of the view that before re-establishing a new life movement (new normal), it is better to precede the transition stage, which is a stage that will determine the success or failure of the new normal stage later. There are two stages of change that can be applied, namely the first stage: the termination stage, then the second stage, the transition stage, which is a procedure in which one gets out of the old habit and enters a new habit or begins with a break and ends with a beginning.

Termination Stage

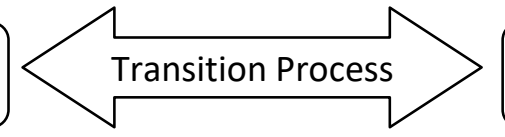

New Normal Era 


\section{Ahnis Zulkarnain, Rizni Restiana}

The author sees that most have not made it through the first phase, people are not disciplined in following health protocols, as a consequence it becomes difficult to enter the next phases, namely the transition phase, let alone the new normal phase. If the transition stage fails to implement changes, it is likely that it will fall into the abyss of destruction and it is very difficult to get back up to the new normal stage, whereas if it succeeds in undergoing the transition stage, it is not absurd that there will be a very significant increase to the new normal stage. Therefore, the authors view the importance of preparing and managing the transition phase as productively and effectively as possible before undergoing the new normal, as indicators have been approved by WHO and the government.

\section{Learning Strategies in the New Normal Transition}

Controversy among the Indonesian people about the opening of schools during the transition to the new normal is becoming increasingly resonant and very dilemmatic. Of course, this has its own arguments. One of the reasons people are pro-school opening is that the school's treasury is running low, so that it requires income to pay teachers, especially private schools. While those who protested, mostly came from the parents/guardians of students. They are afraid because even though they have entered the new normal transition, Covid-19 cases have not completely stopped. Even if you see positive cases are increasing because of the extraordinary testing and tracing by the government. According to the UK, Germany and Vietnam, quoting from detik health on June 04 2020, these 3 countries have decided to return to the New Normal and open schools, but still follow very strict health protocols, such as the school hallways are only used in one direction, mandatory use masks, students in the classroom are limited, teaching time is divided into two waves, the distance between students is 1.5 to 2 meters apart and windows are kept open for air circulation.

The Acting Director General of PAUD, Basic Education and Secondary Education of the Ministry of Education and Culture explained that if the school year is postponed or pushed back to January 2021, there will be several impacts and adjustments so that the school year will continue to be carried out in midJuly 2020 with an online-based learning pattern or not face-to-face learning" (Purba, nd). In response to this, the Indonesian Pediatrician Association (IDAI) proposed to the government that schools remain closed and study online27. In the era of mobile internet, countries around the world have made various effective efforts in online education, but online education is more of a complement to school education, and large-scale normal online education does 
not have many cases. The "School Out, But Class's on" campaign launched by the Chinese government during the COVID-19 epidemic created a normal large-scale online education application 28.

On June 15, 2020, the Ministry of Education and Culture, the Ministry of Religion, the Ministry of Health, and the Ministry of Home Affairs decided to compile guidelines for the implementation of learning in the academic year and the new academic year during the COVID 19 period. Principles of Education Policy in the COVID-19 Pandemic Period with the principles a policy that the health and safety of students, educators, education staff, families, and communities is a top priority in setting learning policies. The pattern of learning patterns for early childhood education, basic education and secondary education, namely the new 2020/2021 teaching will continue to start in July 2020 , for areas that are in the yellow, orange, and red zones, it is prohibited to conduct face-to-face learning in education units. education in these zones continues. Learning from Home29 New normal in the education sector is very different from other sectors of life, so it must be fully alert and careful30.

Based on the situation, general emergency management is the best solution. An emergency policy initiative called "Suspending Classes Without Stopping Learning" aims to turn teaching activities into online teaching31. Distance or online learning has become the norm32. Online learning is very much needed to balance the development of the world of education which is supported by information technology that leads to the digital era, both process and content in the era of the industrial revolution 4.0. With online learning, the learning process can occur anywhere and anytime flexibly33.

Education in this emergency period needs to be distinguished from the normal period. The meaning of "Closing classes without stopping learning" reflects learning in a broad sense, which not only refers to structured learning from the school curriculum, but also includes learning various content. Such learning can be carried out in various ways, the purpose of which is to support student growth. Meanwhile, it was emphasized that knowledge of epidemic prevention and control needs to be included in addition to the formal national curriculum, with particular emphasis on popularizing epidemic prevention knowledge, expressed through life education classes, public safety education and mental health education34.

Public safety education through policy implementation is very important to pay attention to starting from a dynamic process, emergency management system to linking the objectives of all steps, it is appropriate for schools, (principals, teachers and parents) to collaborate to implement a public 


\section{Ahnis Zulkarnain, Rizni Restiana}

emergency management system, which is a procedure which enables emergency decision making and centralized circulation of information, and $\mathrm{n}$ a system for classroom management and multi-level response (Ananda \& Banurea, 2017).

\section{Human Resource Management (HRM) in Improving Learning Strategies in the New Normal Transition Era}

Several schools in Indonesia are closed to prevent the spread of COVID 19 , so the parties who are most disadvantaged are the entire academic community, if schools are closed. However, if observed accurately, students are the ones who feel the most impact. The problem is, if learning stops or is postponed, the time for carrying out learning activities for a year will be delayed until an unspecified time limit. Therefore, education that is oriented towards global relevant needs is very much needed, namely relevant needs (Purba, n.d.).

For this reason, education requires reliable resources, both human resources and infrastructure for educational efficiency. The existence of Covid-19 has encouraged teachers and school academic staff to take a number of policies related to learning activities. As a person who is involved in the world of education, in fact, the author sees the impact of the home-study policy for students starting this March. The scheduled agenda has become a mess, so like it or not, educational institutions must also evaluate policies to anticipate the impact of Covid 19. The abolition of the National Examination, then the final school exam that must be held via WhatsApp is one of the changes faced. The management of educational institutions must be able to adapt to this pandemic and are required to continue to carry out the scheduled routine agenda while maintaining social and psychological distancing.

When learning in educational institutions stops due to this epidemic, public opinion towards educational institutions, especially teachers, will become increasingly positive. In relation to professional competence, the teacher must master, among others:

1. Materials, structures, concepts, and scientific mindsets that support the lessons taught.

2. Understand the competency standards and basic competencies of the subjects/development areas being taught.

3. Elaborating creatively enabled learning materials.

4. Growing professionalism in a sustainable manner by taking introspective actions.

5. Able to use ICT to communicate and develop themselves. (Early, 2021) 
It has been mentioned many times above that it is necessary to have structured collaboration and management, be it teachers, principals and parents, to be able to present online learning. The principal with such a strategic position must be able to display effective leadership, good school management must be accompanied by good teachers, so that the curriculum can be translated into good learning. The effectiveness of a school in achieving its vision, carrying out its mission, meeting goals and targets, and in carrying out learning activities requires the existence of a principal who displays effective leadership.

The forms of school management that can be applied in the new normal era include:

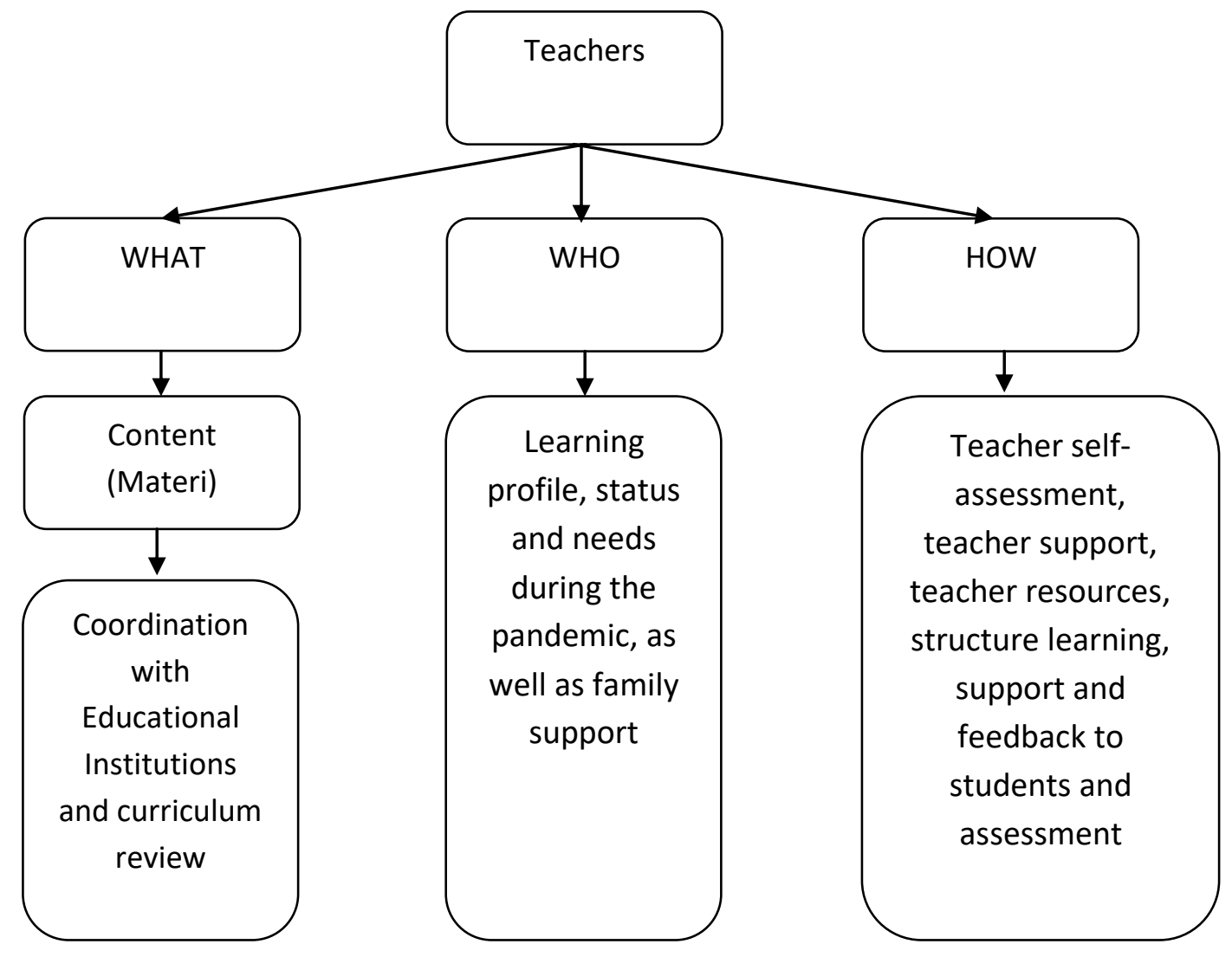




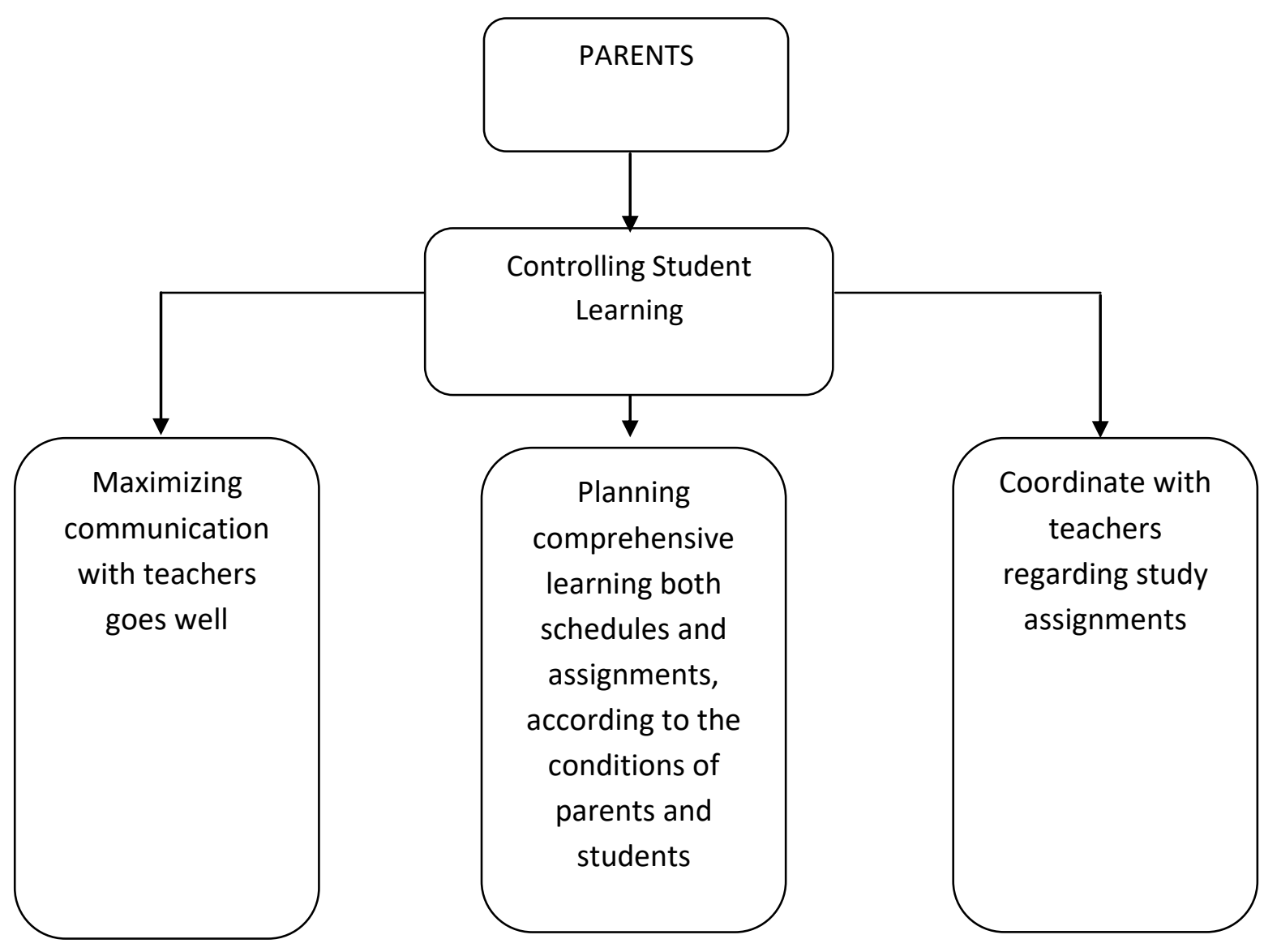

\section{Conclusion}

Human resource management in improving learning strategies in the new normal era is through efforts, mature readiness, debriefing both in terms of ICT skills and the habit of taking virtual learning. The pandemic condition was the beginning of the rise or the establishment of online learning rules for students in Indonesia by the Government and the Ministry of Education and Culture itself, even though previously elite, bona fide schools had already set foot in learning by utilizing technology, but certainly not as dominant as before the pandemic occurred. The most appropriate learning strategy in this new normal era is to follow the rules of the Ministry of Education and Culture with virtual learning through an agreed platform. For this reason, it is necessary to carry out 2 main elements of teaching and learning activities, students and teachers must be equipped, qualified and know the direction of filtered learning in order to minimize misunderstandings between teachers and students. Meanwhile, students at home study with the help and supervision of their parents to avoid 
cheating, laziness and cheating during exams. So that ethics, values / norms are still upheld in the realm of academia. Therefore, this is the basis for the most appropriate learning strategy in this new normal era, the changing times are so fast, ready or not, all regions must follow if they don't want to be left behind. There are big changes and challenges faced by continuing to carry out activities in the midst of a pandemic, but this is a solution. From here, students can learn from the pandemic situation, and stay motivated and guided by teachers to be successful in the future.

\section{References}

Ananda, Rusydi, \& Banurea, Oda Kinata. (2017). Manajemen sarana dan prasarana pendidikan.

Arafah, Novira, \& Bahri, Syamsul. (2020). Peningkatan Human Capital Dalam Proses Pembelajaran di Era New Normal. Jurnal Manajemen Bisnis, 17(3), 425-444.

Dini, JPAU. (2021). Efektivitas Pembelajaran Online Pendidik PAUD di Tengah Pandemi COVID-19. Jurnal Obsesi: Jurnal Pendidikan Anak Usia Dini, 5(1), 686-697.

Fatmawati, Eli. (2020). Kerjasama Orang Tua Dan Guru Dalam Meningkatkan Motivasi Belajar Peserta Didik. IBTIDA', 1(2), 135-150.

Lutfiah, Siti Zakiyatul. (2020). Persepsi Orang Tua Mengenai Pembelajaran Online di Rumah Selama Pandemi Covid-19. Dealektik, 2(2), 69-73.

Miftah sa'adah, Miftah, \& Rakimahwati, Rakimahwati. (2021). PELAKSANAAN STIMULASI KEMAMPUAN SOSIAL ANAK USIA DINI SAAT NEW NORMAL. EARLY CHILDHOOD: JURNAL PENDIDIKAN, 5(1), 89-97.

Purba, Tiara Sani. (n.d.). STRATEGI MANAJEMEN SUMBER DAYA MANUSIA DALAM MENGEMBANGKAN PEMBELAJARAN DI MASA PANDEMI.

Riniwati, Harsuko. (2016). Manajemen Sumberdaya Manusia: Aktivitas Utama dan Pengembangan SDM. Malang: Universitas Brawijaya Press.

Sakban, Sakban, Nurmal, Ifnaldi, \& Ridwan, Rifanto Bin. (2019). Manajemen sumber daya manusia. Alignment: Journal of Administration and Educational Management, 2(1), 93-104. 


\section{Ahnis Zulkarnain, Rizni Restiana}

Siahaya, Vera Th C., Arsawan, I. Wayan Edi, Kennedy, Posma Sariguna Johnson, Dewi, Ni Putu Candra Prastya, \& Aziz, Ismi. (n.d.). NEW NORMAL ERA EDISI II. Zahir Publishing.

Taufik, Taufik, \& Warsono, Hardi. (2020). Birokrasi baru untuk new normal: tinjauan model perubahan birokrasi dalam pelayanan publik di era Covid-19. Dialogue: Jurnal IImu Administrasi Publik, 2(1), 1-18.

\section{Copyright holder :}

Ahnis Zulkarnain, Rizni Restiana (2021)

First publication right :

Devotion : Journal of Research and Community Service

This article is licensed under:

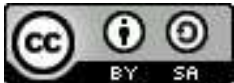

